\title{
FACIAL PATTERN ANALYSIS: CRITIC REVIEW AND COLLECTION OF FACIAL PROPORTIONS IN A BRAZILIAN SAMPLE USING CONE-BEAM COMPUTED TOMOGRAPHY
}

\author{
ANÁLISE DE TIPOS FACIAIS: REVISÃO CRÍTICA E COLETA DE PROPORÇÕES \\ FACIAIS EM AMOSTRA DE BRASILEIROS UTILIZANDO TOMOGRAFIA \\ COMPUTADORIZADA DE FEIXE CONNICO
}

\author{
Thiago Leite BEAINI ${ }^{1}$; Mario CAPPELLETTE JR $^{2}$; Rodolfo F. H. MELANI ${ }^{3}$ \\ 1. Doctor, Professor of the Social and Preventive dentistry department at the Federal University of Uberlândia, Uberlândia, MG, Brazil; \\ 2. Doctor, Coordinator of the mouth-breathing center of UNIFESP- Brazil; 3. Professor of the Social Odontology Department of the \\ University of São Paulo (FOUSP), Coordinator of the Anthropology and Forensic Dentistry Laboratory (OFLAB-USP)
}

\begin{abstract}
The classification of facial vertical patterns is a common practice among dentists of different specialties. It influences treatment planning and expected outcomes, but is usually carried out qualitatively. The aim of this study is to better understand vertical facial proportions, combining a critic review of the literature with the collection of data from 100 Brazilian adult sample in search of 3D quantitative parameters with the use of Cone-Beam Computed Tomography (CBCT) measurements. In Pubmed database, the following quoted phrases were used: "Facial pattern" AND "Facial Index" AND "Facial height Index" AND "Facial height" AND "Dolichofacial" AND "Brachyfacial" AND "Longface syndrome" AND "Short-face syndrome" in a 25 years interval (1990-2015). Study selection was performed searching for crucial facial features, commonly used to determine the facial pattern of a patient. In CBCT exams, 100 patients had facial features measured and classified by the three most reliable methods. The literature on the field can be very confusing, as the methods, landmarks and averages differed considerably. Most of the facial features researched had different values when the literature was analyzed and compared to our data. This indicates that ethnic, age and gender variations play an important whole in facial pattern diagnostic and should be taken in account when using general cephalometric approaches on diagnosis. With a group sorting method, combining the ratios between the anterior Facial height and the width, the anterior vertical proportion and the gonial angle divergence, and with anatomical landmarks we successfully correlated the sample to the qualitative description, as shorter faced patients to larger bi-zygomatic distances and less divergent gonial angles and longer faced patients with narrower and more divergent faces.
\end{abstract}

KEYWORDS: Facial Pattern. Facial index. Vertical facial growth.

\section{INTRODUCTION}

Dentists frequently classify their patients into different vertical facial growth patterns as a step of the malocclusion diagnosis (PROFFIT et al., 2007). If there is a vertical disorder, the earlier patients go through treatment, better are the achievable results, due to the establishment of growth tendencies (NIELSEN, 1991; VAN DER LINDEN, 1999; PROFFIT et al., 2007). Therefore, it influences treatments choices, methods and possible outcomes (PEPICELLI et al., 2005). The vertical facial pattern of a patient have been related to several etiological features, such as the growth of mandible and maxilla, dento-alveolar vertical development, muscle and lips function (NIELSEN, 1991; VAN DER LINDEN, 1999; BOCK et al., 2005), heritability (BAYDAS et al., 2007), among others.

If one researches the subject, the most common definitions, found in the literature, describing the facial types are (COLLETT; WEST, 1993): I. Dolichofacial- Open bite - hiperdivergent
- long face syndrome - Leptoprosopic; II. Brachyfacial - Deep bite - Hypodivergent - Short face syndrome - Euryprosopic; III. Normofacial Mesofacial - Neutraldivergent - Mesoprosopic

The observed multiple terminology itself is a confusing factor among professionals (COLLETT; WEST, 1993), but unfortunately, variations on the topic are not restricted to the nomenclature. There are several analysis and methodologies that can be used to determine rather a person has average facial proportions or belongs to a long or short-face group (PARANHOS et al., 2012).

Description of facial records are found throughout history, as well as different landmarks, measurements and ratios were proposed, with or without the proper background and reliability (MOMMAERTS; MOERENHOUT, 2008). Those landmarks are necessary, as each method requires several referring points on placed over facial features.

The great variability of landmark determination hampers the comparison between indexes and averages from various studies. When 
seeking standards, for clinical or scientific purposes, it becomes hard to decide which data source and method is the most reliable, since there can be discordance of classification when applying different analysis to the same individual (CLARO et al., 2010; PARANHOS et al., 2012) diminishing the relevance of some studies and effectiveness of treatment choices, leading to subjectivity.

From the many exams that can be used for physical anthropology of the skull, few offer so many details than Cone Beam Computed Tomography (CBCT). Precise linear and angular measures can be obtained without influence of magnification and positioning errors, which are critical characteristics of regular radiology (BERCO et al., 2009; HASSAN et al., 2009; MOREIRA et al., 2009; FOURIE et al., 2010; EL-BEIALY et al., 2011; KAPILA et al., 2011; GAIA et al., 2013). Nevertheless, there are limited descriptions of tridimensional (3D) methods for facial pattern diagnosis on CBCT.

The aim of this study is to build a better understanding on vertical facial proportions, combining a critic review of the literature, to verify facial pattern determination guidelines, complemented by the collection of data from 100 Brazilian adult sample, using 3 of the most reliable methods on CBCT exams.

\section{MATERIAL AND METHODS}

\section{Literature review : Search strategy}

A Pubmed (The MEDLINE/Pubmed databases of the National Library of Medicine, Bethesda, Maryland) literature review was performed, searching for articles ranging from 1990-2013, presenting quantitative human data of selected facial features (Table 1). The search was performed in February, 2015.

The quoted keywords were used as follows: "Facial pattern" AND "Facial Index" AND "Facial height Index" AND "Facial height" AND
"Dolichofacial" AND "Brachyfacial" AND "Longface syndrome" AND "Short-face syndrome".

Filters were also added to the search to avoid ineligible results as generated by the Pubmed website:

"Filters activated: Controlled Clinical Trial, Comparative Study, Evaluation Studies, Randomized Controlled Trial, Clinical Trial, Validation Studies, Multicenter Study, Technical Report, Publication date from 1990/01/01 to 2013/12/31, Humans"

\section{Study selection}

Through the abstracts available, were considered eligible only articles in English language, with objective collection of human data, on subjects over 18 years old, males or females. Therefore the main inclusion criteria were the presence of well-described data from at least one of the variables listed on Table 1, as primary or secondary outcome of the research.

The data concerning nomenclature; population; number of subjects; methodology; landmark used to obtain the facial measurements and patient classification data were extracted and compared.

The main rejection criteria were the absence of clear description of the methodology used to calculate indexes or classification of facial pattern, single case reports, pilot or small sample studies (under 20 subjects) and if there were no quantitative measurement reports for the variables on Table 1. Secondary rejection was applied when the article did not have online version, available printed journal or sufficient information in the abstracts in Pubmed's database, hence those were also excluded from this review.

Studies based on post-treatment analysis, and subjects with pathology or genetic anomalies were not considered, unless there were control groups, which data could be considered.

Table 1. Variables collected

\begin{tabular}{lcc}
\hline & Indexes and ratios \\
\hline Facial index $(Z y-Z y / N-M e)$ & FI \\
Facial Height index (ANS-Me/ N-M) & AFI \\
\multicolumn{2}{l}{$\begin{array}{l}\text { Anterior Facial height } \\
\text { Lower anterior facial height }\end{array}$} & LFH \\
Lower posterior facial height (Condilar - Go) & LAFH \\
Bi-Zygomatic breadth & LPFH \\
& Zy-Zy \\
Gonial angle & Angular measures & Go \\
\hline
\end{tabular}




\section{CBCT Measurements and patient classification}

Authors were granted access to a private database of CBCT exams from 2010-2013. From this files, 100 exams were selected, therefore no subject was exposed to radiation for the purpose of this research. The selected clinical exams, had similar protocol of acquisition, with two captures in a total field of view of $20 \mathrm{~cm}$ high and $16 \mathrm{~cm}$ wide with a $120 \mathrm{kVp}$ and $36.90 \mathrm{mAs}$, with a 40 second exposure time applied. Images were reconstructed with a 0.4 voxel size, both captures were merged together, in the tomography's software, so each image file represents the whole facial portion. Images were exported in Digital Imaging Communication in Medicine (DICOM) files and viewed with the aid of the software Osirix, considered suiTable for anthropological measurements (DIAS et al., 2013)

Exams were excluded if the patients showed severe asymmetry or deforming pathology, if traces of previous orthognathic surgery were found or if posterior teeth were missing.

Correct head positioning was obtained artificially with the aid of the software`s tools, in order to attend cephalometric standards (PROFFIT et al., 2007). The axial plane was positioned in tangency of the infra-orbital and Pórion cefalometric points, as the sagittal plane was positioned at the mid-sagittal plane of the patient.

The three most used methods, found in the literature, with distances, angles and indexes were collected from the exams after all landmarks were found with aid of Maximum Intensity Projection (MIP) mode. Angles and distances were obtained with the proper linear and angular measuring tools (Figure. 1) in single slice images as reported to have better precision, as it avoids superimposition of structures (KAPILA et al., 2011).
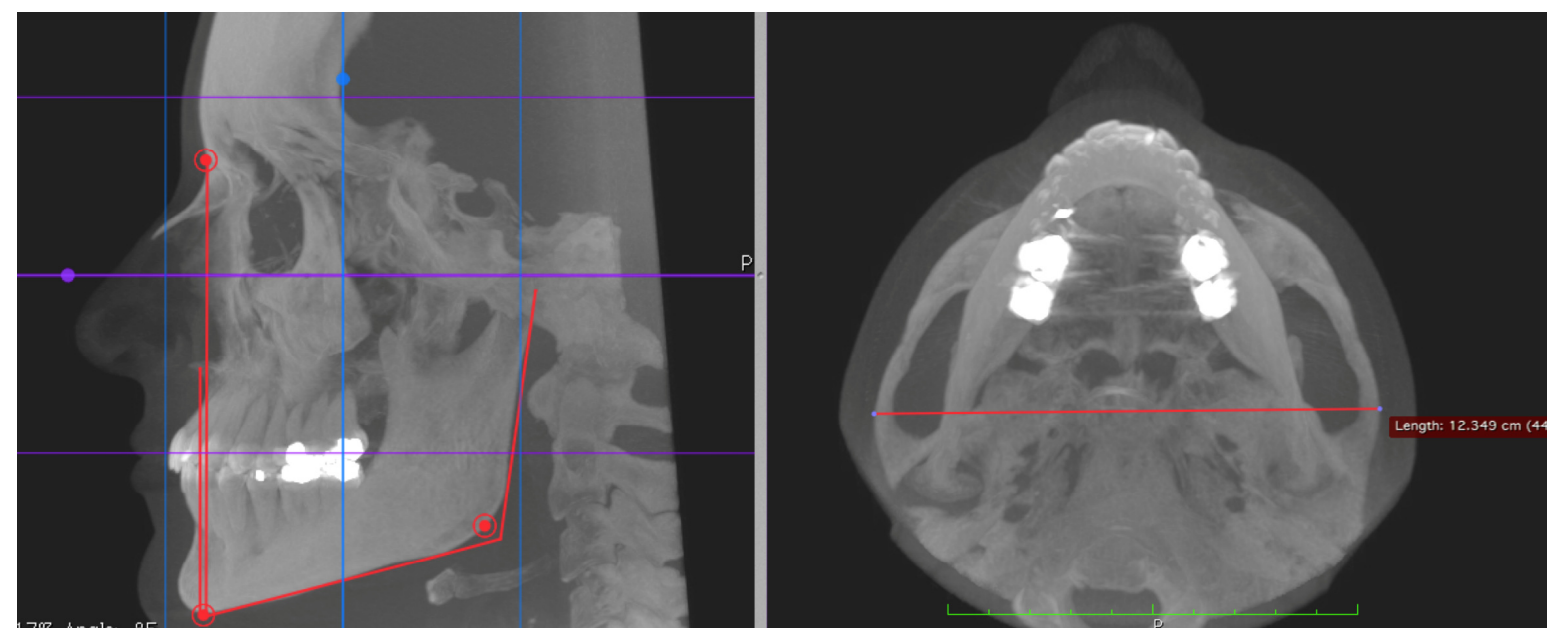

Figure 1. Facial pattern analysis in Computed tomography based on 3 facial features

According to the most common methods found in the literature review, which are described in our results, patients were divided into facial type groups according to standards found in the literature review, where three well established methods for facial height classification were of common use:

A) From Wylie's analysis (WYLIE; JOHNSON, 1952), the Anterior Facial Height Index (AFHI), related to the ratio between Lower Anterior Facial Height and total Anterior Facial Height (LAFH/ AFH) (PROFFIT et al., 2007) with mean values when lower height represents $55 \%( \pm 2 \%)$ of total anterior height.

B) The Facial index (Zi-Zi / N-M) with a normal interval between $80-85 \%$.

C) The Gonial Angle was measured between the mandibular plan and the contour of the mandible`s ramus, with a mean $123^{\circ}( \pm 3 \%)$.
Classification using three parameters occurred when two or more of them showed values of a specific facial type. If all three parameters differed, the patient should be considered in the normal facial group.

\section{Articles included}

Searching the described keywords, results on many areas and expertise were found in Pubmed's database. Interest on patient's facial patterns was found in general dentistry, orthodontics, orthognathic surgery, phonoaudiology, plastic surgery, forensic dentistry, anthropology and many others. If searched separately, results number of each quoted phrase are presented on Table 2. 
Table 2. Absolute number of search results on pubmed database

\begin{tabular}{lll}
\hline Keyword & Results & \\
\hline 1. & Facial Height & 640 \\
2. & Facial pattern & 107 \\
3. & Facial type & 81 \\
4. & Dolichofacial & 53 \\
5. & Brachyfacial & 36 \\
6. & Facial index & \\
7. & Long-face syndrome & 30 \\
8. & Facial height Index & 16 \\
9. & Short-face syndrome & 10 \\
Total & 1003 & \\
\hline
\end{tabular}

A Preferred Reporting Items For Systematic Reviews And Meta-Analysis (PRISMA) flow was followed and when all keywords were searched together with filters applied, a number 225 articles remained. After abstract selection only 13 articles matched the pre-established search criteria.

The report of children data was the main reason for exclusion. Others were rejected because there was just simple mention of one of the key phrases as part of the method to achieve other outcomes, without any new-collected data on any of the variables. Some did not have enough detail of the analysis used, reference intervals or landmarks observed.

In Table 3, there is a sum of the profile of the selected studies. Most had observational, transverse study designs with a single cohort. Among the different exams commonly used in the analysis, we highlight the direct measuring of the face or skull; Postero-Anterior radiograph (PAXray); Lateral radiograph (Lat-XRay) and FanBeam computer tomography (FBCT).

Table 3. Authors and year; number of subjects (n); Age range; Study design and exams used for measuring

\begin{tabular}{|c|c|c|c|c|c|}
\hline Study & $\mathbf{n}$ & Population & Age & Study & Exam \\
\hline $\begin{array}{l}\text { VAN SPRONSEN } \text { et al. } \\
\text { (1992) }\end{array}$ & 48 & $\mathrm{n} / \mathrm{a}$ & Adult & Transv & Lat XRay -MRI \\
\hline RAGHAVAN et al. (1994) & 24 & India & Adult & Transv & Lat and PA Xray \\
\hline TSUNORI et al. (1998) & 39 & Japanese skulls & Adult & Transv & FBCT \\
\hline MASUMOTO et al. (2001) & 31 & Japanese skulls & Adult & Transv & FBCT \\
\hline $\begin{array}{c}\text { SIMPSON e } \\
\text { HENNEBERG (2002) }\end{array}$ & 40 & Australian Cadavers & Adult & Transv & Facial measuring \\
\hline BOCK et al. (2005) & $\begin{array}{c}134 \\
(80 \mathrm{~F} / 54 \mathrm{M})\end{array}$ & Germany & $7-31$ & Transv & Lat Xray \\
\hline BAYDAS et al. (2007) & $\begin{array}{c}138 \\
(68 \mathrm{M} / 70 \mathrm{~F})\end{array}$ & Turkey & $15+$ & Transv & Lat and PA Xay \\
\hline $\begin{array}{c}\text { MOMMAERTS e } \\
\text { MOERENHOUT (2008) }\end{array}$ & 50 & Belgium & Adult & Transv & Facial measure \\
\hline STRAJNIC et al. (2008) & 60 & Serbia & Adult & Transv & Lat Xray \\
\hline TSAI et al. (2009) & 109 & Taiwan & Adult & Transv & Lat Xray \\
\hline MANGLA et al. (2011) & $\begin{array}{c}110 \\
(55 \mathrm{M} / 55 \mathrm{~F})\end{array}$ & India & $18-25$ & Transv & Lat Xray \\
\hline HOSSAIN et al. (2011) & 839 & Japan & Adult & Cohort & Facial measure \\
\hline RITZ-TIMME et al. (2011) & 900 & $\begin{array}{l}300 \mathrm{Germ} / 300 \mathrm{Ita} / \\
300 \text { Lithuanian }\end{array}$ & $20-30$ & Transv & Photo \\
\hline
\end{tabular}




\section{RESULTS}

\section{Most used Landmarks, measures and methods}

Some of the landmarks (Figure. 2) were found in most of the studies and others were specific of one or other method. Gonion (Go), Nasion (N) and Menton (M) points were the most cited and equally placed landmarks but, on the other hand, the Anterior Nasal Spine point (ANS), which usually considered a divisor of the upper and lower anterior facial portions, as well as the upper end of the ramus height, were frequently reported with placement changes and multiple associated points (Figure $3 \mathrm{~A}$ ).

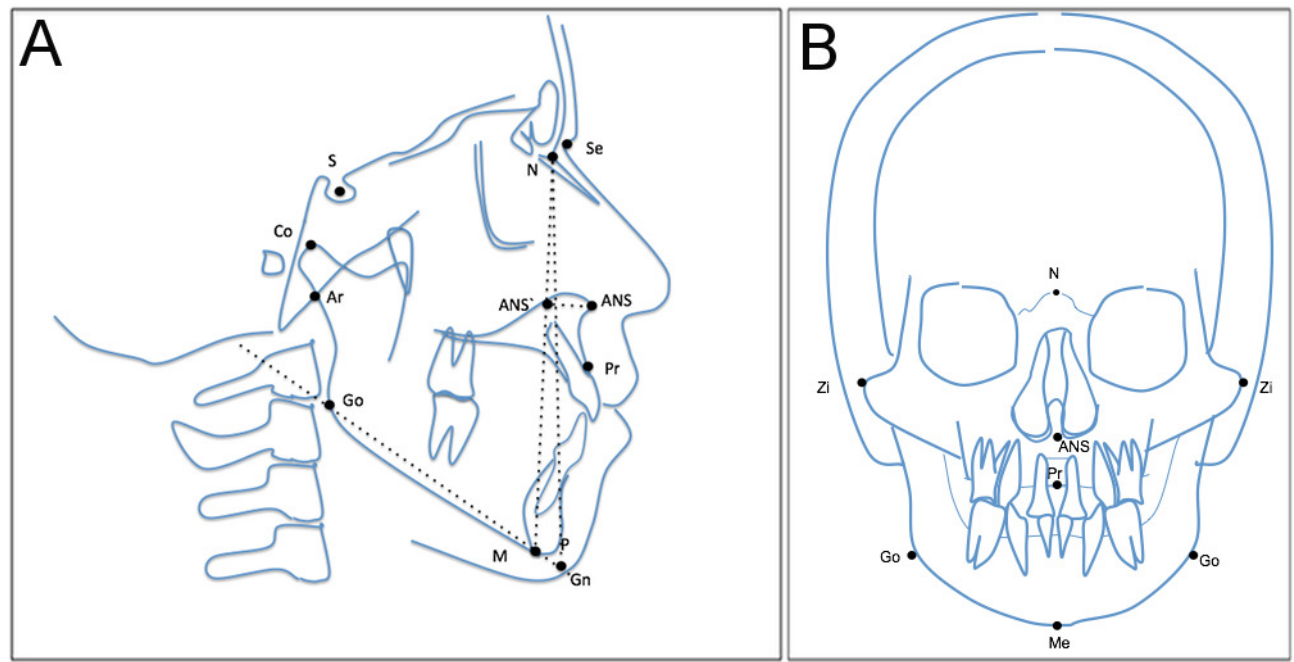

Figure 2. Most Common landmarks in lateral radiographs (A) and in frontal view (B)

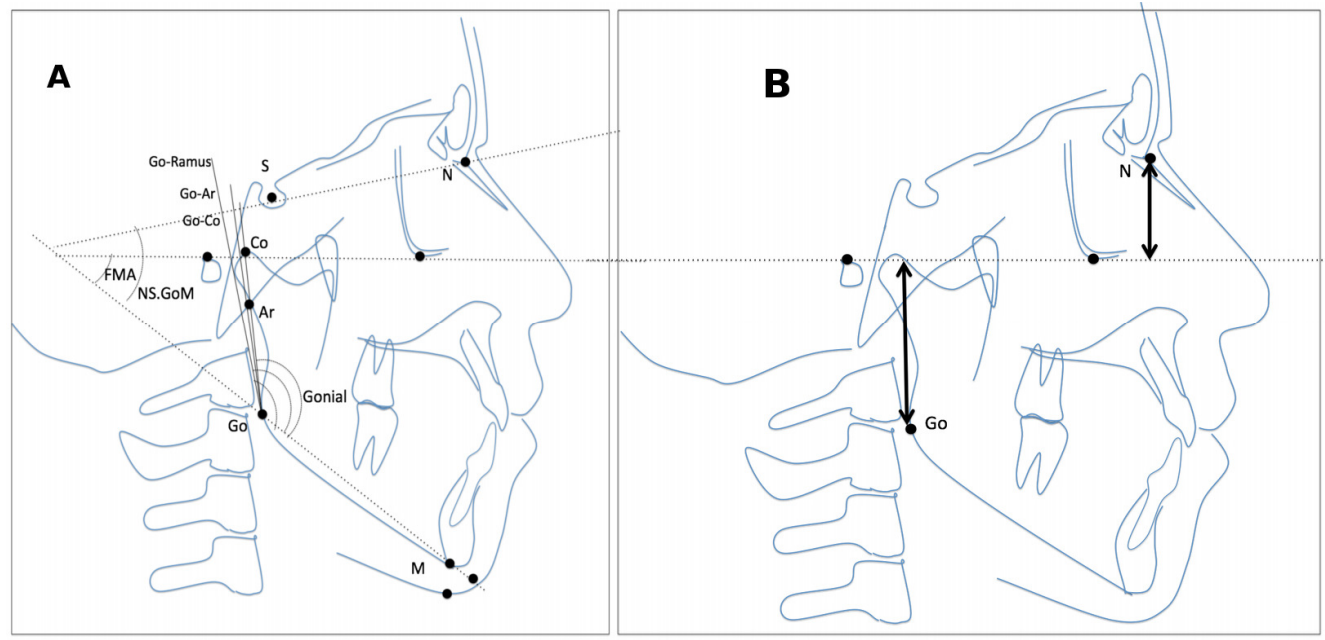

Figure 3. "Condile end" point variation and its impact on Gonial angle (A); Upper and lower facial height when related to the frankfurt plan (B)

The anatomical ANS is placed at the most anterior point of the maxillary bone at the base of nose, but there is also an ANS'. This is a point that is only possible to visualize in lateral radiographs and tomography and is placed at the intersection of the N-Me line with a perpendicular projection of the anatomical ANS (Figure. 2) as proposed by Wylie (WYLIE; JOHNSON, 1952).

The ramus height measure often have it's anatomic end, at the summit of the condyle (Co). But the points used as reference for the gonial angle measurement, may have variation in the literature and was described using the Articular point (Ar), placed at the intersection of the posterior contour of the ramus and base of the skull, and in the most posterior point of the condyle (Figure. 2). Variation on landmarks used causes alteration in angular and linear measuring of this region (Figure. 3).

The term "facial index" proved to be the most confusing of all searched. It often was used to describe the ratio between: UAFH/AFH; $\mathrm{LAFH} / \mathrm{AFH}$ or $\mathrm{PFH} / \mathrm{AFH}$ in the lateral view (Figure. 4- A,B,C). In PA Xrays, direct measuring and photos it was mostly obtained through the ratio 
between the Zy-Zy width with AFH. There was also a Posterior Facial Index obtained as the ratio between the LPFH and PFH (Figure 3- B).

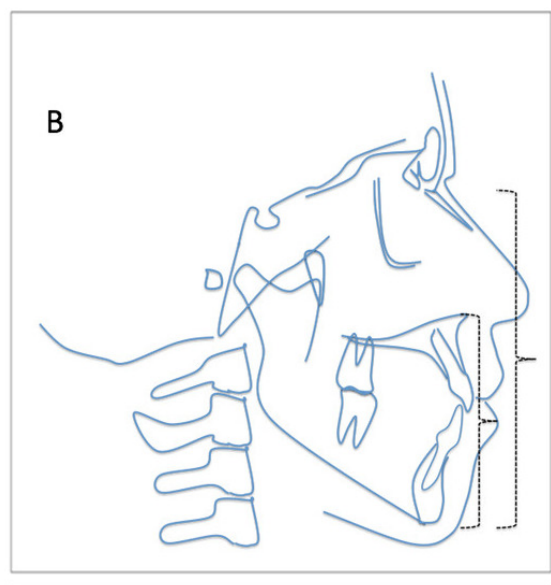

D

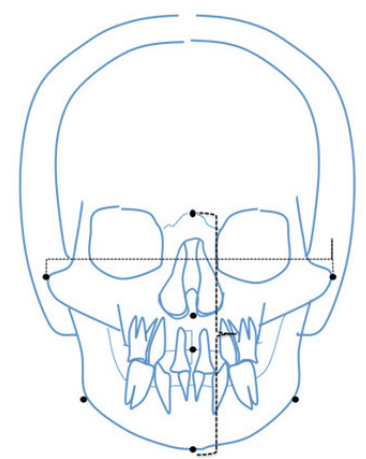

Figure 4. Different interpretation of the term "facial index" in lateral view (A; B and C) and in frontal view (D)

\section{Quantitative data researched}

In Table 4 there is a collection of the measures and ratios searched, extracted or calculate from the information of the 13 articles considered eligible.

Table 4. From the literature, results for Anterior Total, Lower and Upper facial height in millimeters:

\begin{tabular}{|c|c|c|c|c|c|c|c|c|}
\hline Study & $\begin{array}{c}\text { Facial } \\
\text { Type }\end{array}$ & $\begin{array}{c}\text { FI } \\
(\%)\end{array}$ & $\begin{array}{c}\text { AFHI } \\
(\%)\end{array}$ & $\begin{array}{l}\text { AFH } \\
(\mathrm{mm})\end{array}$ & LAFH (mm) & $\begin{array}{c}\text { LPFH } \\
(\mathrm{mm})\end{array}$ & $\begin{array}{l}\text { ZyZy } \\
(\mathrm{mm})\end{array}$ & Go (degrees) \\
\hline \multirow[t]{2}{*}{$\begin{array}{l}\text { Spronsen, et } \\
\text { al. } 1992\end{array}$} & NF & & 57.7 & 127.3 & 73.5 & 54.8 & & $122.2^{\circ}(\mathrm{M})$ \\
\hline & $\mathrm{LF}$ & & 61.3 & 138.6 & 84.9 & 46.6 & & $133.2^{\circ}(\mathrm{M})$ \\
\hline $\begin{array}{l}\text { Raghavan, } \\
\text { et al. } 1994\end{array}$ & NF & & & $130.4^{*}$ & 71.7 & 53.4 & 144 & \\
\hline \multirow{3}{*}{$\begin{array}{l}\text { Tsunori, et } \\
\text { al. } 1998\end{array}$} & SF & & & & & & & $116^{\circ}$ \\
\hline & $\mathrm{NF}$ & & 58 & & & & & $121^{\circ}$ \\
\hline & $\mathrm{LF}$ & & & & & & & $125^{\circ}$ \\
\hline \multirow{3}{*}{$\begin{array}{l}\text { Masumoto, } \\
\text { et al. } 2001\end{array}$} & SF & & & & & & & $119^{o^{3}}$ \\
\hline & $\mathrm{NF}$ & & & & & & & $122^{o 3}$ \\
\hline & $\mathrm{LF}$ & & & & & & & $125^{\circ 3}$ \\
\hline $\begin{array}{c}\text { Simpson, } \\
\text { Hennberg } \\
2002\end{array}$ & NF & $\begin{array}{c}82.2 \\
(\mathrm{M}) \\
81.8 \\
(\mathrm{~F})\end{array}$ & & $\begin{array}{l}138(\mathrm{M}) / \\
124(\mathrm{~F})\end{array}$ & & & $\begin{array}{c}138(\mathrm{M}) / \\
121(\mathrm{~F})\end{array}$ & \\
\hline
\end{tabular}




\begin{tabular}{|c|c|c|c|c|c|c|c|c|}
\hline \multirow{3}{*}{$\begin{array}{l}\text { Bock, et } \\
\text { al.2007 }\end{array}$} & $\mathrm{SF}$ & & & & & & & \\
\hline & $\mathrm{NF}$ & & & & & & & \\
\hline & $\mathrm{LF}$ & & & & & & & $129.4^{0^{3}}$ \\
\hline $\begin{array}{l}\text { Baydas, et } \\
\text { al. } 2007\end{array}$ & NF & & $\begin{array}{l}56.1 \\
(\mathrm{M}) \\
57.1 \\
(\mathrm{~F}) *\end{array}$ & & & & & \\
\hline $\begin{array}{l}\text { Mommaerts, } \\
\text { Moerenhout, } \\
2008\end{array}$ & NF & 87.4 & & 119.4 & & & 134.5 & \\
\hline $\begin{array}{l}\text { Strajnic, et } \\
\text { al. } 2008\end{array}$ & $\mathrm{SF}$ & & & $\begin{array}{c}120(\mathrm{M}) \\
112(\mathrm{~F})\end{array}$ & $67.8(\mathrm{M}) 61.5(\mathrm{~F})$ & & & \\
\hline $\begin{array}{c}\text { Tsai, et al. } \\
2009\end{array}$ & NF & & $\begin{array}{l}55.1 \\
(\mathrm{M}) \\
56.6 \\
(\mathrm{~F})\end{array}$ & $\begin{array}{l}118.2(\mathrm{M}) \\
116.9(\mathrm{~F})\end{array}$ & $65.2(\mathrm{M}) 66.2(\mathrm{~F})$ & $\begin{array}{c}48.5(\mathrm{M}) \\
43.9(\mathrm{~F})\end{array}$ & & \\
\hline \multirow{3}{*}{$\begin{array}{c}\text { Mangla, et } \\
\text { al. } 2009\end{array}$} & $\mathrm{SF}$ & & & & & $\begin{array}{l}55(\mathrm{M}) \\
53(\mathrm{~F})\end{array}$ & & $\begin{array}{c}121.8^{\circ}(\mathrm{M}) \\
122^{\circ}(\mathrm{F})^{2}\end{array}$ \\
\hline & $\mathrm{NF}$ & & & & & $\begin{array}{l}53(\mathrm{M}) \\
48(\mathrm{~F})\end{array}$ & & $\begin{array}{c}125.7^{\circ}(\mathrm{M}) 127^{\circ} \\
(\mathrm{F})^{2}\end{array}$ \\
\hline & $\mathrm{LF}$ & & & & & $\begin{array}{l}46(\mathrm{M}) \\
46(\mathrm{~F})\end{array}$ & & $\begin{array}{c}131^{\circ}(\mathrm{M}) \\
133.6^{\circ}(\mathrm{F})^{2}\end{array}$ \\
\hline $\begin{array}{l}\text { Hossain, et } \\
\text { al. } 2011\end{array}$ & NF & $82 *$ & & 114 & & & 138.49 & \\
\hline $\begin{array}{l}\text { Ritz-Timme, } \\
\text { et al. } 2011\end{array}$ & NF & $88.1^{*}$ & & $\begin{array}{c}118.4 \\
\text { (Mean) }\end{array}$ & & & $\begin{array}{c}135.5 \\
\text { (Mean) }\end{array}$ & \\
\hline
\end{tabular}

NF- Normal Face; LF- Long Face; SF- Short Face; M- Male; F- Female; * Data calculated from available information, not in original Paper

\section{Quantitative data obtained from CBCT}

On Table 5 the report of the sample studied in the 100 individual with CBCT, sorted based on the analysis of facial height and width, anterior facial proportions and the gonial angle.

Table 5. Results of this research's facial features

\begin{tabular}{lcccccccc}
\hline & \multicolumn{9}{c}{ Female } & \multicolumn{4}{c}{ Male } \\
\hline SF & FI $(\%)$ & Min & max & SD & FI $(\%)$ & Min & $\max$ & SD \\
NF & 83.72 & 73.83 & 90.6 & 6.82 & 84.97 & 81.8 & 87.93 & 1.94 \\
LF & 88.07 & 82.76 & 91.92 & 6.99 & 90.01 & 79.13 & 98.33 & 5.79 \\
& 97.36 & 90.73 & 107.89 & 6.64 & 97.27 & 91.28 & 105.71 & 3.75 \\
SF & AFHI $(\%)$ & Min & max & SD & AFHI $(\%)$ & Min & $\max$ & SD \\
NF & 53.09 & 50.26 & 58.88 & 3.03 & 56.08 & 49.65 & 60.22 & 3.71 \\
LF & 56.25 & 51.09 & 59.82 & 2.99 & 56.56 & 52.53 & 61.7 & 2.59 \\
& 58.7 & 50.33 & 62.25 & 3.06 & 58.85 & 55.5 & 63.48 & 2.23 \\
SF & AFH (mm) & Min & Max & SD & AFH (mm) & Min & Max & SD \\
NF & 103.37 & 93.1 & 112.02 & 5.62 & 112.01 & 105.24 & 122.34 & 6.37 \\
LF & 108.48 & 103.75 & 114.3 & 3.97 & 116.79 & 107.31 & 128.6 & 6.94 \\
& 116.19 & 101.2 & 125.82 & 6.14 & 124.04 & 115.56 & 135.06 & 5.4 \\
SF & LAFH (mm) & Min & Max & SD & LAFH (mm) & Min & Max & SD \\
NF & 54.92 & 48.78 & 62.93 & 4.57 & 62.9 & 53.37 & 70.3 & 6.4 \\
LF & 61.08 & 53.01 & 67.3 & 4.21 & 66.07 & 58.22 & 76.11 & 5.24 \\
& 68.18 & 60.6 & 75.2 & 4.1 & 73.05 & 64.84 & 83.53 & 5.19
\end{tabular}




\begin{tabular}{lcccccccc} 
& LPFH $(\mathrm{mm})$ & Min & Max & SD & LPFH $(\mathrm{mm})$ & Min & Max & SD \\
SF & 51.44 & 44.1 & 58.84 & 4.72 & 63.64 & 58.7 & 73.91 & 4.91 \\
NF & 54.43 & 42.48 & 64.39 & 5.2 & 63.32 & 58.97 & 69.33 & 2.56 \\
LF & 52.16 & 33.67 & 60.9 & 6.2 & 59.27 & 47.43 & 71.15 & 5.51 \\
& Zy-Zy (mm) & Min & Max & SD & Zy-Zy $(\mathrm{mm})$ & Min & Max & SD \\
SF & 123.54 & 119.4 & 126.7 & 2.58 & 131.75 & 122.25 & 143.05 & 6.58 \\
NF & 123.24 & 115.11 & 129.79 & 4.76 & 129.88 & 123 & 140.47 & 5.41 \\
LF & 119.39 & 108.73 & 129.73 & 4.93 & 127.6 & 115.22 & 141 & 5.3 \\
& Gonial Angle & & & & Gonial Angle & & & \\
& (degrees) & Min & max & SD & (degrees) & Min & max & SD \\
SF & 119.41 & 115.00 & 123.40 & 7.97 & 115.24 & 106.00 & 123.00 & 5.87 \\
NF & 121.44 & 115.00 & 132.00 & 8.15 & 121.52 & 107.00 & 135.00 & 7.10 \\
LF & 129.01 & 114.00 & 154.00 & 8.21 & 129.55 & 118.00 & 143.69 & 6.11 \\
\hline
\end{tabular}

From the 100 individual examined, there were coincidence on the diagnosis of all three methods in 42 cases, only two of the methods in 50 cases and complete discordance in eight cases. The most discordant one was the anterior facial index, followed by the gonial angle and the facial index respectively.

\section{DISCUSSION}

The use of this critic review of the literature to support group sorting and data comparison of a research was thought to be the only solution when facing the confusion from varied and conflicted information regarding facial types. The lack of clear standards for landmarks placing, measurements, and reference values used in scientific studies impairs the comparison of new data as well as clinical diagnosis from one study to another.

The limited number of studies selected was influenced by the choice for an adult population, as most studies are performed with focus on subjects through growth phases. But the variation among the many age groups would add a number of variables for this research, as the facial features and standards change greatly during the first 18 years of life (RICKETTS, 1957; PROFFIT et al., 2007; CLARO et al., 2010).

Many papers cited the use of a method but did not offer any data in the results section. If an author reports that patients were grouped according to a certain method, they expected that the whole professional community should understand it. This practice favors the repetition of known information, regardless of the population, age and sex of the original sample in the cited methods. Most of the analyses were originally created for the use in children or teenagers, but are widely applied to adult samples. Ricketts, for example, analyzed 1000 patients in one of his articles (RICKETTS, 1960) but only 33 were over 18 years old. It is certain that the known methods have incontesTable contribution to dentistry, but repeating it "blindly" is a behavior no longer suiTable in evidence-based sciences.

In our data, we found great variation not only among facial types but also between Male and Female subjects. This fact alerts for the common practice of using a single average value to both genders. Baral, et al. (BARAL et al., 2010) reported the same conclusion, and also observed that the variation among age groups were also significant to vertical proportions in children.

Comparing the researched results and our data, there has been some similarity with previous results, but most differed considerably, highlighting the differences between populations. Contributing to the hypothesis of regional variation, Ritz-Timme et al. (RITZ-TIMME et al., 2011) described measures of 3 different European population: 300 Germans, 300 Italians and 300 Lithuanian. In their results a considerable amount of differences was observed, in a small geographic region inside Europe, which also infer a concern with the use of the same standards to every population.

Hossain et al. (HOSSAIN et al., 2011) found significant variation, in a long term study, among members of the Japanese population, within a 20 year interval inferring that the human face not only changes due to gender, age and racial aspects but also historically in a population, demanding constant studies regarding ethnic, age and sex groups.

When classifying vertical facial types, abundant discordance is found, diagnosing the same individuals through different known methods (CLARO et al., 2010; PARANHOS et al., 2012) a result also verified in this research. Therefore we chose the use of three anatomical features that 
provided a vertical facial proportion, a ratio between height and width as well as the divergence of the mandibular plan. Some methods sort an individual into a facial pattern based on a single measurement or ratio and only in lateral view. After analyzing the literature and our results, we were lidded to conclude that single measures may be very inaccurate for facial classification (RAMIRES et al., 2011).

The numbers of this sample, agreed with previous descriptions as successfully correlated shorter faced individuals to larger bi-zygomatic distances and less divergent gonial angles and the opposite occurred to longer faced patients with narrower and more divergent faces.

The Gonial Angle divergence and the FI had better correlation to the final classification, when compared to the AFHI, not always conclusive, as it only considers a lateral view of facial height of the patient. It is our suggestion to always have the analysis based in multiple known features, in order to conclude with over-all based analysis.

The CBCT was considered the best source for recording multiple data in one exam, with reliability of the measuring and little influence of positioning errors (BERCO et al., 2009; FOURIE et al., 2010; EL-BEIALY et al., 2011). The Landmarks were also chosen to allow the analysis in other radiographic exams or direct measure in patients and dry skulls collection, providing helpful data and standards for anthropometric studies, as we avoided internal landmarks, usual in other radiographic cephalometry, such as the Sella $(\mathrm{S})$.

The literature on the field can be very confusing, as the methods, landmarks and averages differed considerably. Most of the facial features researched had different values when the literature was analyzed and compared to our data. This indicates that ethnic, age and gender variations play an important whole in facial pattern diagnostic and should be taken in account when using general cephalometric approaches on diagnosis.

The use of multiple analysis is advisable, as the combination of the quantitative analysis of the ratio between the anterior Facial height and the width, the anterior vertical proportion and the gonial angle divergence, successfully correlated patients with the qualitative descriptions, such as shorter faced individuals to larger bi-zygomatic distances and less divergent gonial angles and longer faced patients with narrower and more divergent faces.

\section{ACKNOWLEDGEMENTS}

Authors would like to thank CAPES for granting scholarships. Also to INDOR and its professionals, in the person of Prof. Dr. Israel Chilvarquer for the support.

RESUMO: A classificação de padrões faciais verticais é prática comum entre Cirurgiões Dentistas de diferentes especialidades. Esta influencia o planejamento de tratamento e resultados esperados, no entanto, essa tarefa é frequentemente realizada de forma qualitativa. $\mathrm{O}$ objetivo deste trabalho foi compreender melhor as proporções verticais da face, combinando uma análise crítica da literatura com a coleta de dados de 100 adultos brasileiros na procura por parâmetros quantitativos em 3D, usando tomografias computadorizada de feixe cônico (TCFC). Na base de dado pubmed, a seguinte frase foi utilizada: "Facial pattern" AND "Facial Index" AND "Facial height Index" AND "Facial height" AND "Dolichofacial" AND "Brachyfacial" AND "Long-face syndrome" AND "Short-face syndrome" em um intervalo de 25 anos (1990-2015). A seleção dos estudos foi realizada procurando características faciais cruciais e métodos comuns para a determinação do padrão facial do paciente. Em exames de TCFC de 100 pacientes adultos, foram medidas as dimensões faciais foram registradas e os três métodos mais confiáveis e encontrados na literatura foram testados. A literatura sobre o assunto pode ser muito confusa, ao ponto de que os métodos, pontos de referência e médias variaram consideravelmente. Muitas das características pesquisadas tinham valores diferentes quando analisada a literatura em comparação com os dados dessa pesquisa. Isso indica que variações de etnia, idade e gênero tem papel importante no diagnóstico do padrão facial e deve ser levada em consideração quando utilizados padrões cefalométricos para diagnóstico. Com a metodologia de agrupamento, utilizando o índice entre a altura facial anterior e a largura, a proporção anterior da face e a divergência do ângulo goníaco, assim como os pontos cefalométricos selecionados, nós correlacionamos com sucesso a amostra com as descrições qualitativas como: os pacientes de face curta e as distâncias bi-zigomáticas e ângulos faciais menos divergentes, assim como os pacientes de face longa com faces mais estreitas e menos divergentes.

PALAVRAS CHAVE: Tipo Facial. Índice Facial. Crescimento facial vertical. 


\section{REFERENCES}

BARAL, P. et al. An anthropometric study of facial height among four endogamous communities in the Sunsari district of Nepal. Singapore Med J, v. 51, n. 3, p. 212-5, Mar 2010.

BAYDAS, B.; ERDEM, A.; YAVUZ, I.; CEYLAN, I. Heritability of facial proportions and soft-tissue profile characteristics in Turkish Anatolian siblings. Am J Orthod Dentofacial Orthop, v. 131, n. 4, p. 504-9, Apr 2007. https://doi.org/10.1016/j.ajodo.2005.05.055

BERCO, M. et al. Accuracy and reliability of linear cephalometric measurements from cone-beam computed tomography scans of a dry human skull. Am J Orthod Dentofacial Orthop, v. 136, n. 1, p. 17 e1-9; discussion 17-8, Jul 2009.

BOCK, J. J.; BOCK, F.; BOHM, B.; FUHRMANN, R. A. Classification of anterior open bite using individualized cephalometry. J Orofac Orthop, v. 66, n. 5, p. 338-48, Sep 2005.

https://doi.org/10.1007/s00056-005-0330-x

CLARO, C. A.; ABRAO, J.; REIS, S. A. Association between overbite and craniofacial growth pattern. Braz

Oral Res, v. 24, n. 4, p. 425-32, Oct-Dec 2010. https://doi.org/10.1590/S1806-83242010000400009

COLLETT, A. R.; WEST, V. C. Terminology of facial morphology in the vertical dimension. Aust Dent J, v. 38, n. 3, p. 204-9, Jun 1993. https://doi.org/10.1111/j.1834-7819.1993.tb03065.x

DIAS, P. E. M.; BEAINI, T. L.; MELANI, R. F. H. Evaluation of osifix software with craniofacial anthropometric purposes. Journal of Research in Dentistry, v. 1, n. 4, p. 351-367, 2013. Disponível em: < http://www.portaldeperiodicos.unisul.br/index.php/JR_Dentistry/article/view/1845 >.

EL-BEIALY, A. R.; FAYED, M. S.; EL-BIALY, A. M.; MOSTAFA, Y. A. Accuracy and reliability of conebeam computed tomography measurements: Influence of head orientation. Am J Orthod Dentofacial Orthop, v. 140, n. 2, p. 157-65, Aug 2011. https://doi.org/10.1016/j.ajodo.2010.03.030

FOURIE, Z.; DAMSTRA, J.; GERRITS, P. O.; REN, Y. Accuracy and reliability of facial soft tissue depth measurements using cone beam computer tomography. Forensic Sci Int, v. 199, n. 1-3, p. 9-14, Jun 152010. https://doi.org/10.1016/j.forsciint.2010.02.018

GAIA, B. F.; PINHEIRO, L. R.; UMETSUBO, O. S.; COSTA, F. F.; CAVALCANTI, M. G. Comparison of precision and accuracy of linear measurements performed by two different imaging software programs and obtained from 3D-CBCT images for Le Fort I osteotomy. Dentomaxillofac Radiol, v. 42, n. 5, p. 20120178, 2013. Disponível em: < http://www.ncbi.nlm.nih.gov/pmc/articles/PMC3635772/pdf/dmfr-42-5-D12178.pdf >.

HASSAN, B.; VAN DER STELT, P.; SANDERINK, G. Accuracy of three-dimensional measurements obtained from cone beam computed tomography surface-rendered images for cephalometric analysis: influence of patient scanning position. Eur J Orthod, v. 31, n. 2, p. 129-34, Apr 2009.

https://doi.org/10.1093/ejo/cjn088

HOSSAIN, M. G.; SAW, A.; OHTSUKI, F.; LESTREL, P. E.; KAMARUL, T. Change in facial shape in two cohorts of Japanese adult female students twenty years apart. Singapore Med J, v. 52, n. 11, p. 818-23, Nov 2011.

KAPILA, S.; CONLEY, R. S.; HARRELL, W. E., JR. The current status of cone beam computed tomography imaging in orthodontics. Dentomaxillofac Radiol, v. 40, n. 1, p. 24-34, Jan 2011.

https://doi.org/10.1259/dmfr/12615645 
MANGLA, R.; SINGH, N.; DUA, V.; PADMANABHAN, P.; KHANNA, M. Evaluation of mandibular morphology in different facial types. Contemp Clin Dent, v. 2, n. 3, p. 200-6, Jul-Sep 2011. https://doi.org/10.4103/0976-237X.86458

MASUMOTO, T.; HAYASHI, I.; KAWAMURA, A.; TANAKA, K.; KASAI, K. Relationships among facial type, buccolingual molar inclination, and cortical bone thickness of the mandible. Eur J Orthod, v. 23, n. 1, p. 15-23, Feb 2001. https://doi.org/10.1093/ejo/23.1.15

MOMMAERTS, M. Y.; MOERENHOUT, B. A. Reliability of clinical measurements used in the determination of facial indices. J Craniomaxillofac Surg, v. 36, n. 5, p. 279-84, Jul 2008.

https://doi.org/10.1016/j.jcms.2007.11.005

MOREIRA, C. R.; SALES, M. A.; LOPES, P. M.; CAVALCANTI, M. G. Assessment of linear and angular measurements on three-dimensional cone-beam computed tomographic images. Oral Surg Oral Med Oral Pathol Oral Radiol Endod, v. 108, n. 3, p. 430-6, Sep 2009. https://doi.org/10.1016/j.tripleo.2009.01.032

NIELSEN, I. Vertical malocclusions: etiology, development, diagnosis and some aspects of treatment. Angle Orthod., v. 61, n. 4, p. 247-60., Winter 1991.

PARANHOS, L. R. et al. Correlation of different cephalometric measurements to define facial type. Int J Orthod Milwaukee, v. 23, n. 1, p. 31-7, Spring 2012.

PEPICELLI, A.; WOODS, M.; BRIGGS, C. The mandibular muscles and their importance in orthodontics: a contemporary review. Am J Orthod Dentofacial Orthop, v. 128, n. 6, p. 774-80, Dec 2005.

https://doi.org/10.1016/j.ajodo.2004.09.023

PROFFIT, W. R.; FIELDS, H. W.; SARVER, D. M. Contemporary Orthodontics. 4th. Saint Louis: Mosby, 2007.

RAGHAVAN, R.; SIDHU, S. S.; KHARBANDA, O. P. Craniofacial pattern of parents of children having cleft lip and/or cleft palate anomaly. Angle Orthod, v. 64, n. 2, p. 137-44, 1994.

RAMIRES, R. R.; FERREIRA, L. P.; MARCHESAN, I. Q.; CATTONI, D. M.; SILVA, M. A. Proposal for facial type determination based on anthropometry. J Soc Bras Fonoaudiol, v. 23, n. 3, p. 195-200, Sep 2011. https://doi.org/10.1590/S2179-64912011000300003

RICKETTS, R. M. Planning treatment on the basis of the facial pattern and an estimate of its growth. Angle Orthod, v. 27, n. 1, p. 14-37, 1957.

. Foundation for cephalometric communication. Am J Orthod v. 46, n. 5, p. 330-57, 1960. https://doi.org/10.1016/0002-9416(60)90047-6

RITZ-TIMME, S. et al. Metric and morphological assessment of facial features: a study on three European populations. Forensic Sci Int, v. 207, n. 1-3, p. 239 e1-8, Apr 152011.

SIMPSON, E.; HENNEBERG, M. Variation in soft-tissue thicknesses on the human face and their relation to craniometric dimensions. Am J Phys Anthropol, v. 118, n. 2, p. 121-33, Jun 2002.

https://doi.org/10.1002/ajpa.10073

STRAJNIC, L.; STANISIC-SINOBAD, D.; MARKOVIC, D.; STOJANOVIC, L. Cephalometric indicators of the vertical dimension of occlusion. Coll Antropol, v. 32, n. 2, p. 535-41, Jun 2008.

TSAI, H. H.; HO, C. Y.; LEE, P. L.; TAN, C. T. Sex differences in anthropometric and cephalometric characteristics in the severity of obstructive sleep apnea syndrome. Am J Orthod Dentofacial Orthop, v. 135, n. 2, p. 155-64, Feb 2009. https://doi.org/10.1016/j.ajodo.2008.10.001 
TSUNORI, M.; MASHITA, M.; KASAI, K. Relationship between facial types and tooth and bone characteristics of the mandible obtained by CT scanning. Angle Orthod, v. 68, n. 6, p. 557-62, Dec 1998.

VAN DER LINDEN, F. P. G. M. The Development of long and short faces and their limitations in treatment. R Dental Press Ortodon Ortop Facial, v. 4, n. 6, p. 6-11, 1999.

VAN SPRONSEN, P. H.; WEIJS, W. A.; VALK, J.; PRAHL-ANDERSEN, B.; VAN GINKEL, F. C. A comparison of jaw muscle cross-sections of long-face and normal adults. J Dent Res, v. 71, n. 6, p. 1279-85, Jun 1992. https://doi.org/10.1177/00220345920710060301

WYLIE, W. L.; JOHNSON, E. L. Rapid evaluation of facial dysplasia in the vertical plane. Angle Orthod, v. 22, n. 3, p. 165-182, 1952. 